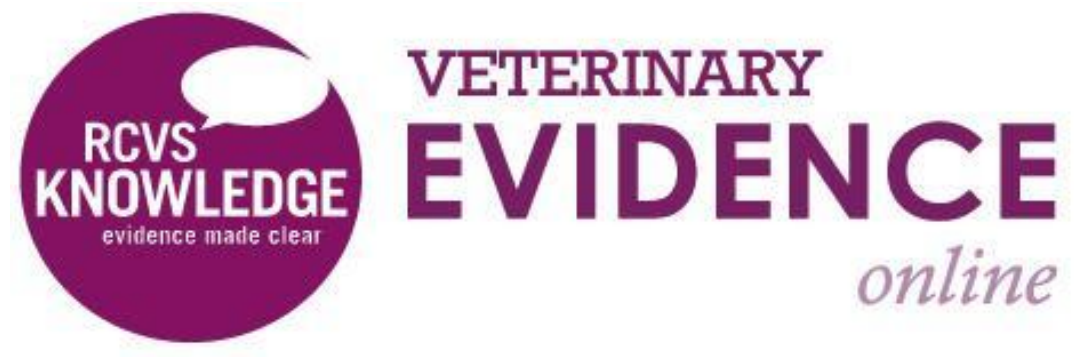

\title{
Are Old Dogs Who Undergo Total Hip Replacement More Predisposed to Perioperative Femoral Fractures Than Young Dogs?
}

A Knowledge Summary by

Valentine Jacot DVM ${ }^{1 *}$

${ }^{1}$ Vetsuisse Faculty University of Zurich Rämistrasse 71, 8006 Zürich, Switzerland
${ }^{*}$ Corresponding Author (vjacot@vetclinics.uzh.ch)

ISSN: 2396-9776

Published: 22 June 2016

in: Vol 1, Issue 2

DOI: http://dx.doi.org/10.18849/ve.v1i2.28

Reviewed by: Nina Kieves (DVM, DACVS-SA, DACVSMR)

Next Review Date: 20 Jan 2018 


\section{KNOWLEDGE SUMMARY}

\section{Clinical bottom line}

There is currently insufficient evidence that old dogs undergoing total hip replacement are more predisposed to perioperative femoral fractures in comparison to young dogs.

\section{Question}

Are old dogs undergoing total hip replacement more predisposed to perioperative femoral fracture in comparison to young dogs?

\section{The evidence}

By reviewing the veterinary literature relative to the general complications and outcomes of total hip arthroplasty, a variation in the prevalence of femoral fractures was noticed. Regarding the design of these studies, the level of evidence provided is weak. Currently, there are insufficient strongly convincing studies in the veterinary literature.

\section{Summary of the evidence}

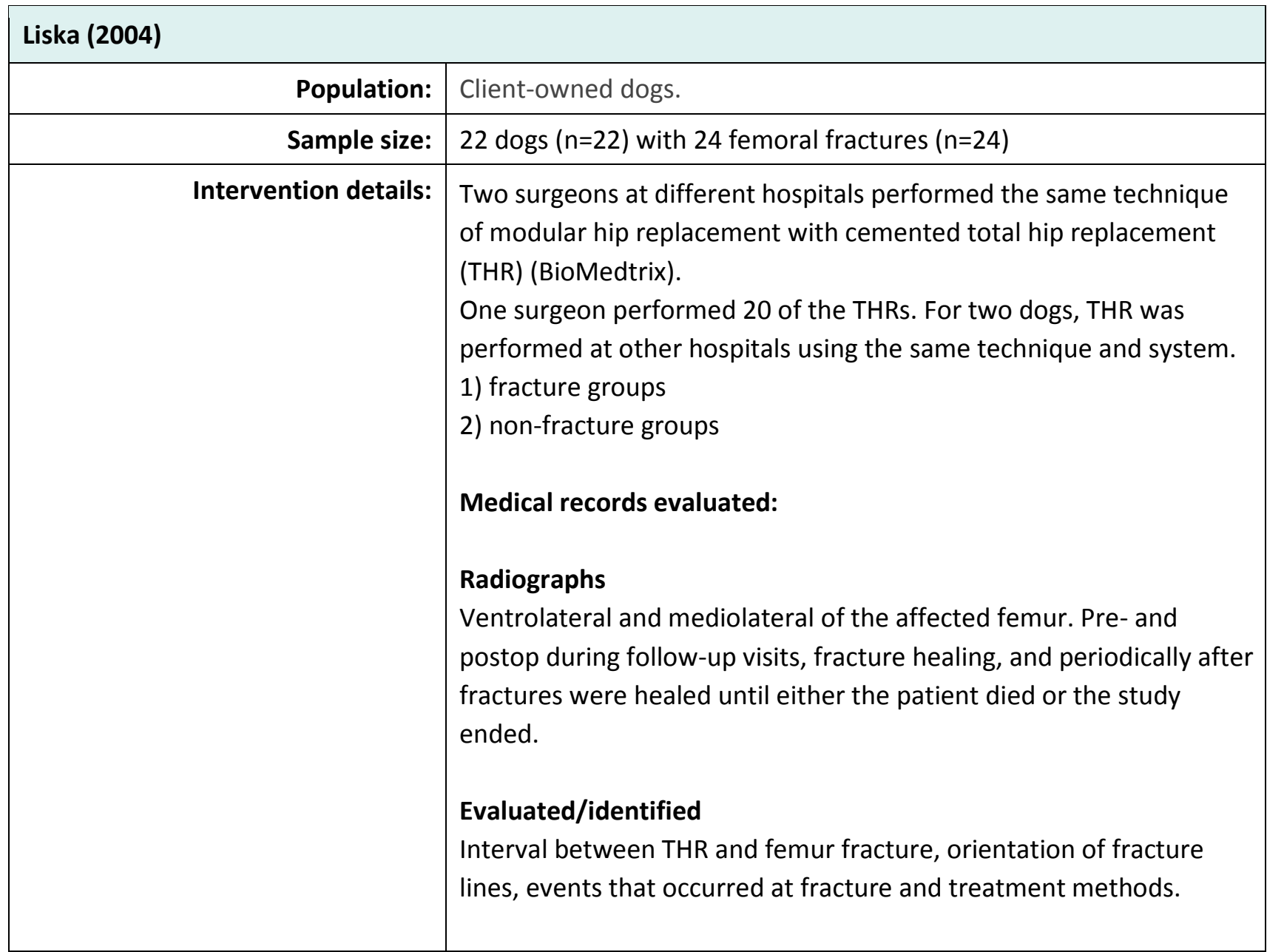




\begin{tabular}{|c|c|}
\hline & $\begin{array}{l}\text { Patient information } \\
\text { Fixation method, joint alignment, bone healing implant integrity, } \\
\text { bone-cement interface, implant-cement interface. } \\
\text { Limb function } \\
\text { Evaluated by examination and client interview and classified as } \\
\text { either normal or good. } \\
\text { Mean, median and range of numerical values were calculated for } \\
\text { variables such as age, body weight, body score, bone healing and } \\
\text { follow-up intervals. } \\
\text { T-tests to compare fracture group and non-fracture group. }\end{array}$ \\
\hline Study design: & Retrospective observational case-control study. \\
\hline Outcome studied: & $\begin{array}{l}\text { Objective: } \\
\text { To report femur fracture as a complication of THR and to report the } \\
\text { incidence, predisposing factors, treatment options and outcome. }\end{array}$ \\
\hline $\begin{array}{l}\text { Main findings: } \\
\text { (relevant to PICO question): }\end{array}$ & $\begin{array}{l}\text { Overall incidence of femur fracture after THR: } 2.9 \% \text {. } \\
\text { Age at THR } \\
\text { Dogs that had femur fractures were significantly older ( } 7.4 \text { years) at } \\
\text { THR than dogs that did not sustain femur fractures ( } 4.9 \text { years) } \\
\text { ( } p=0.0063 \text { ). } \\
\text { Predisposing factors } \\
\text { Osteopathy ( } n=5 \text { ) iatrogenic fissures created during reaming ( } n=9 \text { ) } \\
\text { and previous hip surgery. } \\
\text { Fracture characteristics } \\
\text { Fracture occurrence } \\
22 \text { after original THR, } 1 \text { after revision, } 1 \text { after explanation: } \\
\text { - traumatic events in } 17 \text { dogs } \\
\text { - osteopathy present at THR in } 5 \text { dogs } \\
\text { - cortical thinning secondary to aseptic loosening in } 3 \text { dogs } \\
\text { Fracture treatment: } \\
\text { - plate and screw fixation ( } 10 \text { with and } 7 \text { without cerclage } \\
\quad \text { wires) resulted in the most favourable outcome - healing } \\
\text { occurred in } 6-10 \text { weeks } \\
\text { - full cerclages wires in } 3 \text { dogs } \\
\text { - } \quad \text { eutrict confinement in } 3 \text { dogs } \\
\text { Outcome: } \\
\text { - } 22 \text { fractures healed and there were no non-unions } 1 \text { dog } \\
\text { two fractures that did not heal: } 1 \text { dog died } 16 \text { days after } \\
\text { without treatment }\end{array}$ \\
\hline
\end{tabular}




\begin{tabular}{|c|c|}
\hline & $\begin{array}{l}\text { - } 20 \text { clients with a dog with a healed fracture were } \\
\text { interviewed }>65 \text { days after surgery: } 12 \text { dogs were alive at } \\
\text { the end of the study - } 15 \text { clients ( } 75 \%) \text { reported normal limb } \\
\text { function and } 5(25 \%) \text { reported good limb function } \\
\text { Old dogs with osteopathies, dogs that have had previous hip } \\
\text { surgery, and dogs that have intraoperative fissures should be } \\
\text { recognised as potentially being at greater risk of femoral fracture. }\end{array}$ \\
\hline Limitations: & $\begin{array}{l}\text { - } \quad \text { retrospective study } \\
\text { - } \text { different surgeons, different hospitals } \\
\text { - } \quad \text { surgeon experience was not evaluated as a risk factor } \\
\text { - } \text { different follow-up } \\
\text { - } 10 \text { dogs }(45.5 \%) \text { with fractures were followed until death } \\
\text { - } \quad \text { client interview }\end{array}$ \\
\hline
\end{tabular}

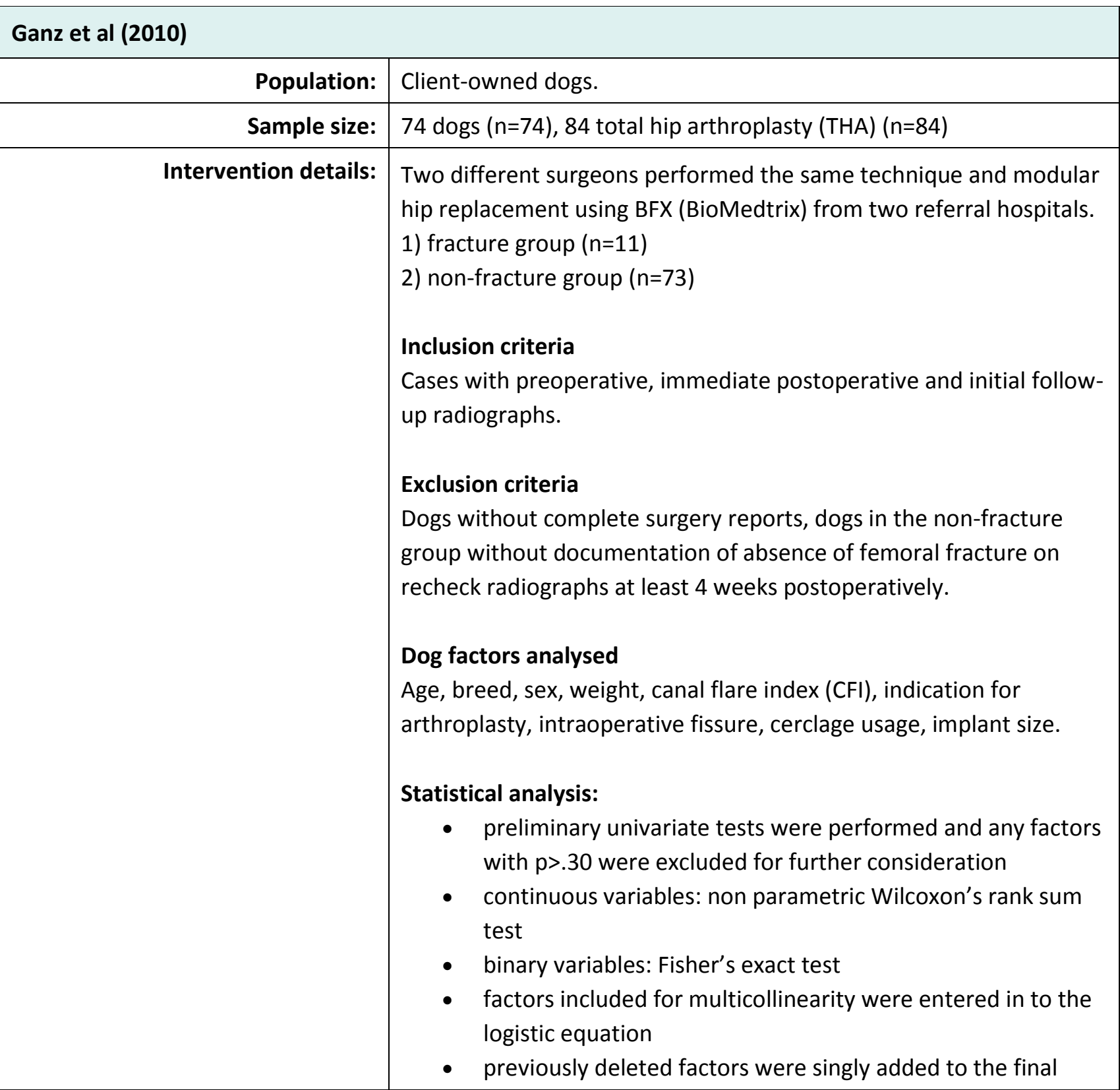




\begin{tabular}{|c|c|}
\hline & model to reassess significance \\
\hline Study design: & Retrospective observational cases cohort study. \\
\hline Outcome studied: & $\begin{array}{l}\text { To evaluate risk factors for femoral fracture after porous-coated } \\
\text { cementless THA. }\end{array}$ \\
\hline $\begin{array}{l}\text { Main findings: } \\
\text { (relevant to PICO question): }\end{array}$ & 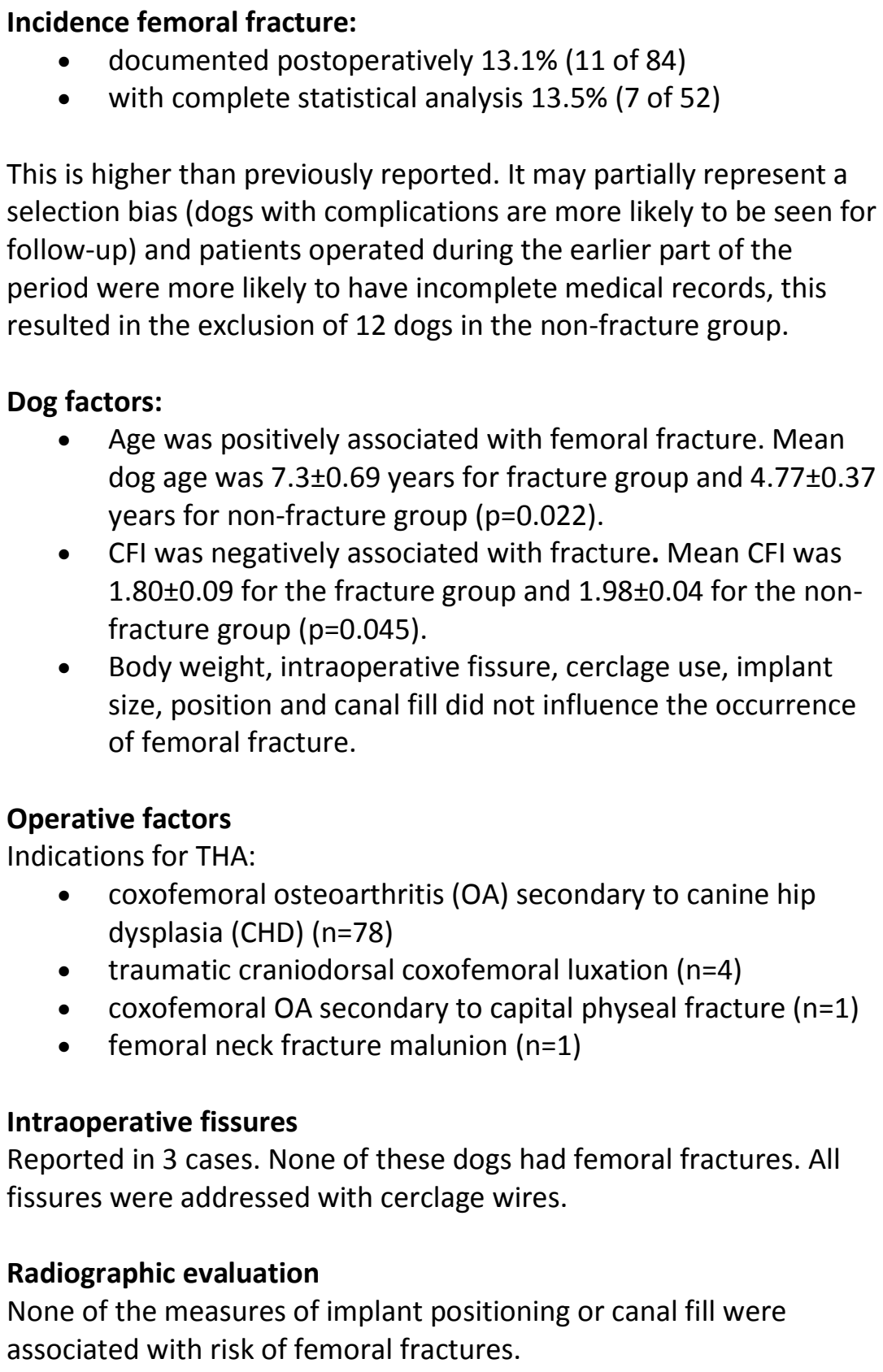 \\
\hline Limitations: & $\begin{array}{l}\text { - } \text { - } \text { small number of dogs in the fracture group (may have led to } \\
\text { type II error) } \\
\text { - different surgeons with } 2 \text { slightly different methods, } 2 \\
\text { different hospitals and surgeon experience was not } \\
\text { evaluated as a risk factor } \\
\text { - partial selection bias possible } \\
\text { - } \text { quality of radiographic positioning varied among patients } \\
\text { radiographs not evaluated from a board diplomate in }\end{array}$ \\
\hline
\end{tabular}




\begin{tabular}{|l|l|}
\hline & radiology \\
& - canal flare index (CFI) not always available \\
& - length of radiographic and clinical follow-up varied \\
& - body score missing \\
\hline
\end{tabular}

\begin{tabular}{|c|c|}
\hline \multicolumn{2}{|l|}{ Hummel et al (2010) } \\
\hline Population: & Client-owned dogs that underwent Zurich cementless THR. \\
\hline Sample size: & 163 dogs $(n=163)$ \\
\hline Intervention details: & $\begin{array}{l}\text { Inclusion criteria } \\
\text { At least } 8 \text { weeks of documented postoperative radiographic and } \\
\text { orthopaedic evaluations. } \\
\text { Exclusion criteria } \\
\text { THR performed as the second procedure in dogs operated bilaterally, } \\
\text { previous ipsilateral coxofemoral surgery, cases without sufficient } \\
\text { client communication. } \\
\text { Medical records of dogs } \\
\text { Sex, breed, age, body weight, body condition score, side of } \\
\text { arthroplasty, date of surgery, history of previous contralateral } \\
\text { coxofemoral surgery, urinalysis results, intraoperative surgical site } \\
\text { culture results, lameness score at presentation (0=no lameness, } \\
\text { 1=slight lameness, } 2=\text { obvious weight-bearing lameness, } \\
3=\text { intermittent non-weight bearing lameness, } 4=\text { continuous non- } \\
\text { weight-bearing lameness) size of prostheses implanted, duration of } \\
\text { surgery. } \\
\text { Complications were separated into: } \\
\text { - intraoperative (IOC) } \\
\text { - short-term (STC) } \\
\text { long-term (LTC) } \\
\text { Bivariate and multivariate statistical analysis was used to compare } \\
\text { complications. } \\
\text { Procedures were performed by } 10 \text { different surgeons. }\end{array}$ \\
\hline Study design: & Retrospective cohort study. \\
\hline Outcome studied: & $\begin{array}{l}\text { To determine the prevalence of complications and identify } \\
\text { prognostic indicators of success or failure for the Zurich cementless } \\
\text { THR. }\end{array}$ \\
\hline $\begin{array}{l}\text { Main findings: } \\
\text { (relevant to PICO question): }\end{array}$ & $\begin{array}{l}\text { Increased body weight } \\
\text { Prior femoral head and neck ostectomy }(\mathrm{FHO}) \text { or cemented-THR in } \\
\text { the contralateral joint was identified as a negative prognostic } \\
\text { indicator for successful outcome }(p<0.05) \text {. }\end{array}$ \\
\hline
\end{tabular}




\begin{tabular}{|c|c|}
\hline & $\begin{array}{l}\text { IOC } \\
\text { overall IOC rate }=11 \% \\
\text { - fracture of the femoral diaphysis }(n=12)=7.4 \% \\
\text { - } \text { fracture of the greater trochanter }(n=3) \\
\text { - } \quad \text { imcessive haemorrhage }(n=1) \\
\text { STC } \\
\text { overall STC rate=6.75\% } \\
\text { - coxofemoral luxation }(n=6) \\
\text { - } \text { transient neuraprexia }(n=2) \\
\text { - fracture of the femoral diaphysis }(n=2)(1.2 \%) \\
\text { LTC } \quad \text { fracture of the acetabulum }(n=1) \\
\text { overall LTC rate=10.4\% } \\
\text { - septic loosening ( } n=6) \\
\text { - coxofemoral luxation }(n=6) \\
\text { implant failure }(n=4) \\
\text { fracture of the femoral diaphysis }(n=1)(0.6 \%)\end{array}$ \\
\hline Limitations: & $\begin{array}{l}\text { - } \quad \text { retrospective } \\
\text { - } \quad \text { surgery performed by } 10 \text { different surgeons } \\
\text { - } \text { persons } \\
\text { - } \quad \text { relatively short scheduled radiographic follow-up ( } 8 \text { weeks) } \\
\text { - } 50 \text { cases in which the } 8 \text { week follow-up was not performed } \\
\text { by board certified specialists (surgery and radiology), body } \\
\text { score not evaluated in all dogs } \\
\text { - increased rate of complications higher than previous } \\
\text { studies. Likely influenced in part by varying degrees of Z-THR } \\
\text { experience (technical error) } \\
\text { - } \quad \text { surgeon's experience not evaluated as prognostic factor } \\
\text { no evaluation of technical errors immediately post } \\
\text { operatively }\end{array}$ \\
\hline
\end{tabular}

\begin{tabular}{|c|c|}
\hline \multicolumn{2}{|l|}{ Bergh et al (2006) } \\
\hline Population: & $\begin{array}{l}\text { Client-owned dogs that underwent cTHR at the University of } \\
\text { Pennsylvania School of Veterinary Medicine. }\end{array}$ \\
\hline Sample size: & 97 dogs $(n=97)$ \\
\hline Intervention details: & $\begin{array}{l}\text { Medical records } \\
\text { Signalement, body weight, body condition score, diagnosis at the } \\
\text { time of surgery, history of previous or subsequent hip surgery. } \\
\text { Complications }\end{array}$ \\
\hline
\end{tabular}




\begin{tabular}{|c|c|}
\hline & $\begin{array}{l}\text { - intraoperative (IOC) } \\
\text { - } \text { short term (STC) } \\
\text { Evaluation of radiographs } \\
\text { 2-view radiographic hip studies pre-operatively, immediately post- } \\
\text { operatively and at the longest follow-up were evaluated by one } \\
\text { investigator. } \\
\text { Pre-operatively } \\
\text { Severity of osteoarthritis (OA) was graded (0=normal, } 1=\text { subtle, } \\
\text { 2=grade } 0 \text { or } 1 \text { with severe subluxation or luxation, 3=mild OA, } \\
\text { 4=moderate OA, 5=severe OA). } \\
\text { Immediately post-operatively } \\
\text { Surgical technique (implant size, implant position, cement quality) } \\
\text { and technical errors. } \\
\text { Radiographs at the longest available follow-up and at least at } 8 \\
\text { weeks post-operatively } \\
\text { Evaluated and compared to the immediate post-operative films } \\
\text { (fracture of cement, medullary infection, loosening of the acetabular } \\
\text { component, prosthetic luxation, fracture of the femoral diaphysis or } \\
\text { greater trochanter and infection). } \\
\text { Statistical analysis: } \\
\text { - categorical data: chi-square or Fisher's exact test } \\
\text { Surgery performed by various board certified surgeons } \\
\text { contribution of possible risk factors }\end{array}$ \\
\hline Study design: & Retrospective cohort study. \\
\hline Outcome studied: & $\begin{array}{l}\text { To identify the prevalence of complications and changes following } \\
\text { CTHR and to identify factors that may predispose to a need for } \\
\text { revision surgery. }\end{array}$ \\
\hline $\begin{array}{l}\text { Main findings: } \\
\text { (relevant to PICO question): }\end{array}$ & $\begin{array}{l}\text { Prevalence of complications: } \\
\text { 12.1\% after primary cTHR } \\
\text { Pre-operative radiographs: } \\
\text { - } \quad \text { available for } 79 \text { dogs } \\
\text { - } \text { majority had severe OA } \\
\text { Post-operative radiographs (primary cTHR) ( } \mathbf{n}=\mathbf{9 7}) \text { : } \\
\text { - } \quad \text { available for } 87 \text { dogs } \\
\text { - } 69 \text { dogs had appropriately sized femoral implants } \\
\text { - } 60 \text { dogs had eccentrically placed implants }\end{array}$ \\
\hline
\end{tabular}




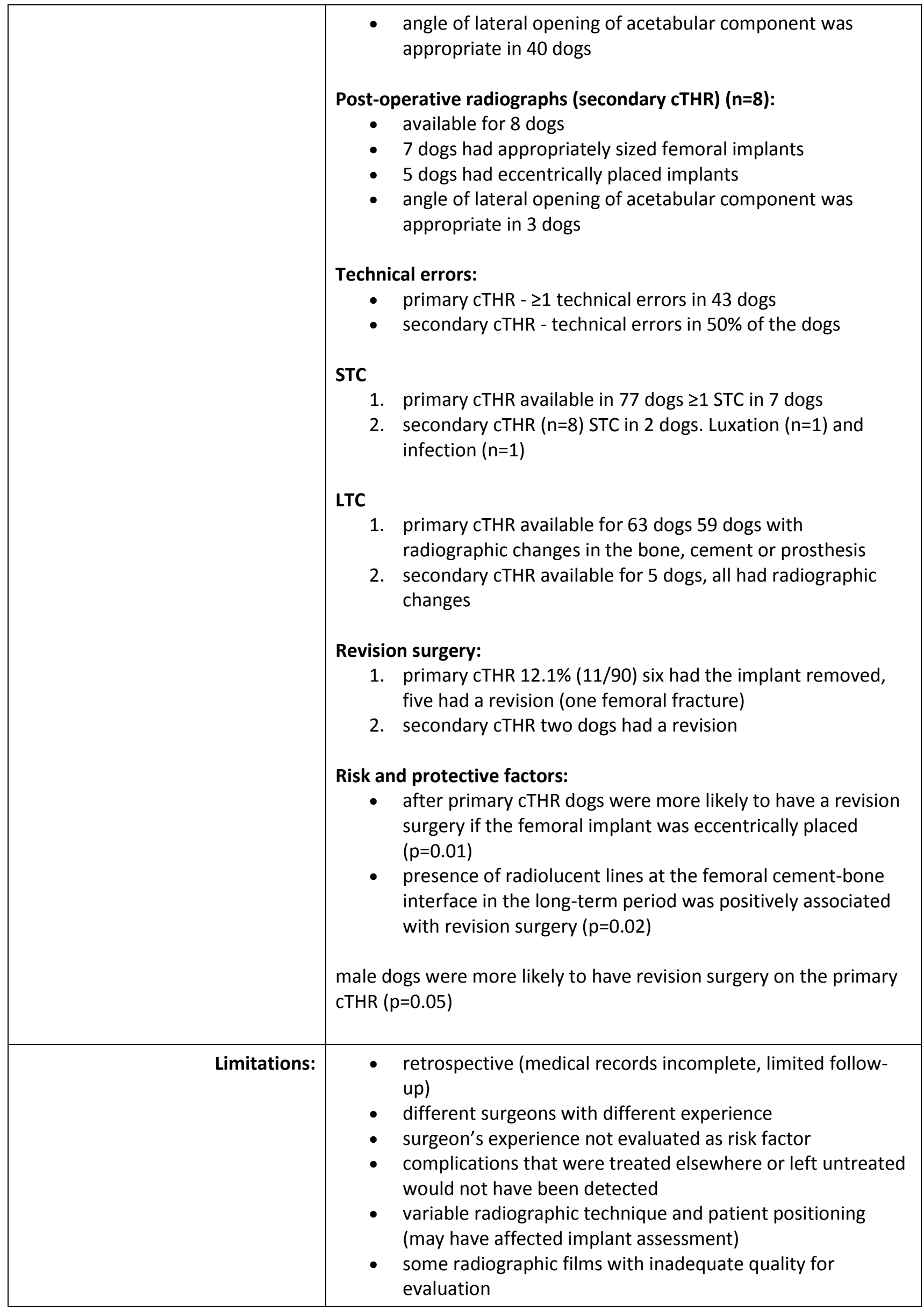




\begin{tabular}{|c|c|}
\hline \multicolumn{2}{|l|}{ Guerrero (2009) } \\
\hline Population: & $\begin{array}{l}\text { Client-owned dogs that had Zurich Cementless Total Hip } \\
\text { Replacement (ZCTHR). } \\
\text { Inclusion criteria: } \\
\text { Medical records of the first } 100 \text { consecutives cases with } \\
2^{\text {nd }} \text { generation ZCTHR were reviewed. Only those dogs that had } \\
\text { clinical and radiographic evaluation with } \geq 6 \text { months follow-up. }\end{array}$ \\
\hline Sample size: & 60 dogs $(n=60) 65$ ZCTHR $(n=65)$ \\
\hline Intervention details: & $\begin{array}{l}\text { All surgery was performed by the same surgeon. } \\
\text { Signalement data: } \\
\text { - } \quad \text { age, breed, body weight, gender } \\
\text { - } \quad \text { hip dysplasion for THR } \\
\text { conservative and/or surgical management of traumatic } \\
\text { coxofemoral luxation ( } n=5 \text { ), old Salter-Harris fracture of the } \\
\text { proximal femoral physis ( } n=1 \text { ) } \\
\text { - } \quad \text { date of surgery and operated size } \\
\quad \text { Al) } \\
\text { Longest clinical and radiographic follow-up (presence of pain on } \\
\text { manipulation of the hip joint, range of motion (ROM), muscle mass } \\
\text { compared with the contralateral size, lameness). Evaluated using a } \\
\text { score: excellent, good, fair, poor or failed. } \\
\text { Complications: } \\
\text { - } \quad \text { intraoperative ( } n=1 \text { ) femoral fissure during reaming } \\
\text { post-operative ( } n=11 \text { ) femoral fracture (1), prosthesis } \\
\text { luxation ( } 7 \text { ), cup loosening ( } 2 \text { ), implant failure (1) } \\
\text { Management of complications and outcome } \\
\text { Nine cases were successfully revised. Explanation of implants was } \\
\text { performed in one case because of infection, one dog was euthanised } \\
\text { after a new luxation. }\end{array}$ \\
\hline Study design: & Retrospective descriptive case series. \\
\hline Outcome studied: & To evaluate the use of, and to identify complications of the ZCTHR. \\
\hline $\begin{array}{l}\text { Main findings: } \\
\text { (relevant to PICO question): }\end{array}$ & $\begin{array}{l}\text { Mean follow-up: } \\
22.68+/-16.75 \text { months }\end{array}$ \\
\hline
\end{tabular}




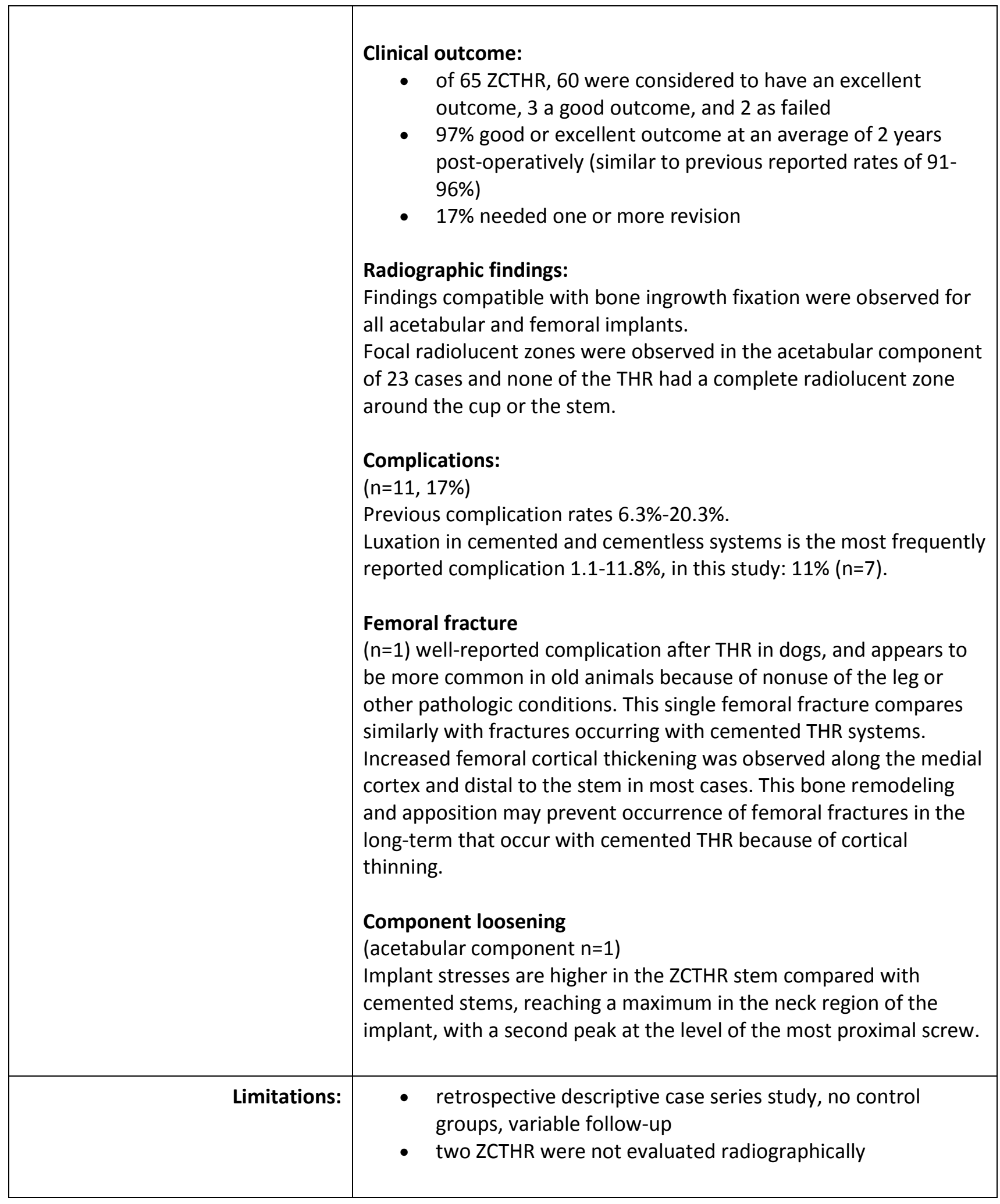

\section{Forster et al (2012)}

\begin{tabular}{|r|l|}
\hline Population: & Client-owned dogs that underwent THR. \\
\hline Sample size: & 170 dogs $(\mathrm{n}=170)$ \\
\hline Intervention details: & $\begin{array}{l}\text { Entries into the British Veterinary Orthopaedic Association-Canine } \\
\text { hip Registry (BVOA-CHR) were reviewed. }\end{array}$ \\
\hline
\end{tabular}




\begin{tabular}{|c|c|}
\hline & $\begin{array}{l}\text { Variables evaluated: } \\
\text { - age, body weight, breed, indication for THR and prosthesis } \\
\text { Statistical analysis: } \\
\text { - } \quad \text { association between each variable and the incidence of } \\
\text { complications were assessed using logistic regression } \\
\text { - Mann-Whitney U-Test was performed to assess the } \\
\text { significance of total lameness scores before and after THR } \\
\text { Owner outcomes assessment questionnaire was used additionally to } \\
\text { collect data from owners. } \\
\text { Divided in } 4 \text { sections: } \\
\text { - Section A assessed information regarding length of ongoing } \\
\text { mobility problem, medications received, and other } \\
\text { concurrent medical history unrelated to hip dysplasia (HD). } \\
\text { - Section B assessed activity and willingness to exercise before } \\
\text { THR. } \\
\text { - Section C assessed date of surgery, overall owner } \\
\text { satisfaction and complications. } \\
\text { Section D assessed activity and willingness to exercise after } \\
\text { THR. }\end{array}$ \\
\hline Study design: & Prospective case series. \\
\hline Outcome studied: & $\begin{array}{l}\text { To assess the variables associated with the complications of THR and } \\
\text { report owner-assessed outcomes, through surgeon-based } \\
\text { registration of cases via an online database, informed owner consent } \\
\text { and prospective outcomes assessment using a client-administered } \\
\text { clinical metrology instrument. }\end{array}$ \\
\hline $\begin{array}{l}\text { Main findings: } \\
\text { (relevant to PICO question): }\end{array}$ & $\begin{array}{l}\text { Complications } \\
\text { Incidence: } 9.4 \% \text { : } \\
\text { - luxation ( } n=5) \\
\text { - } \quad \text { minor wound dehiscence } \\
\text { - }(n=1) \text { wound sepsis, }(n=1) \text { protrusion acetabuli, }(n=1) \\
\text { acetabular cup displacement, }(n=1) \text { suspected pulmonary } \\
\text { thromboembolism and death at the end of surgery } \\
\text { - }(n=1) \text { femoral pain, }(n=1) \text { femoral subsidence, }(n=1) \text { siatic } \\
\quad \text { paresis and luxation }(n=5), \text { femoral fracture }(n=3) \text {, minor } \\
\text { wound dehiscence }(n=1) \\
\text { No statistical significance was identified between weight, age, } \\
\text { gender, breed, indication for THR, surgical technique and prosthesis }\end{array}$ \\
\hline
\end{tabular}




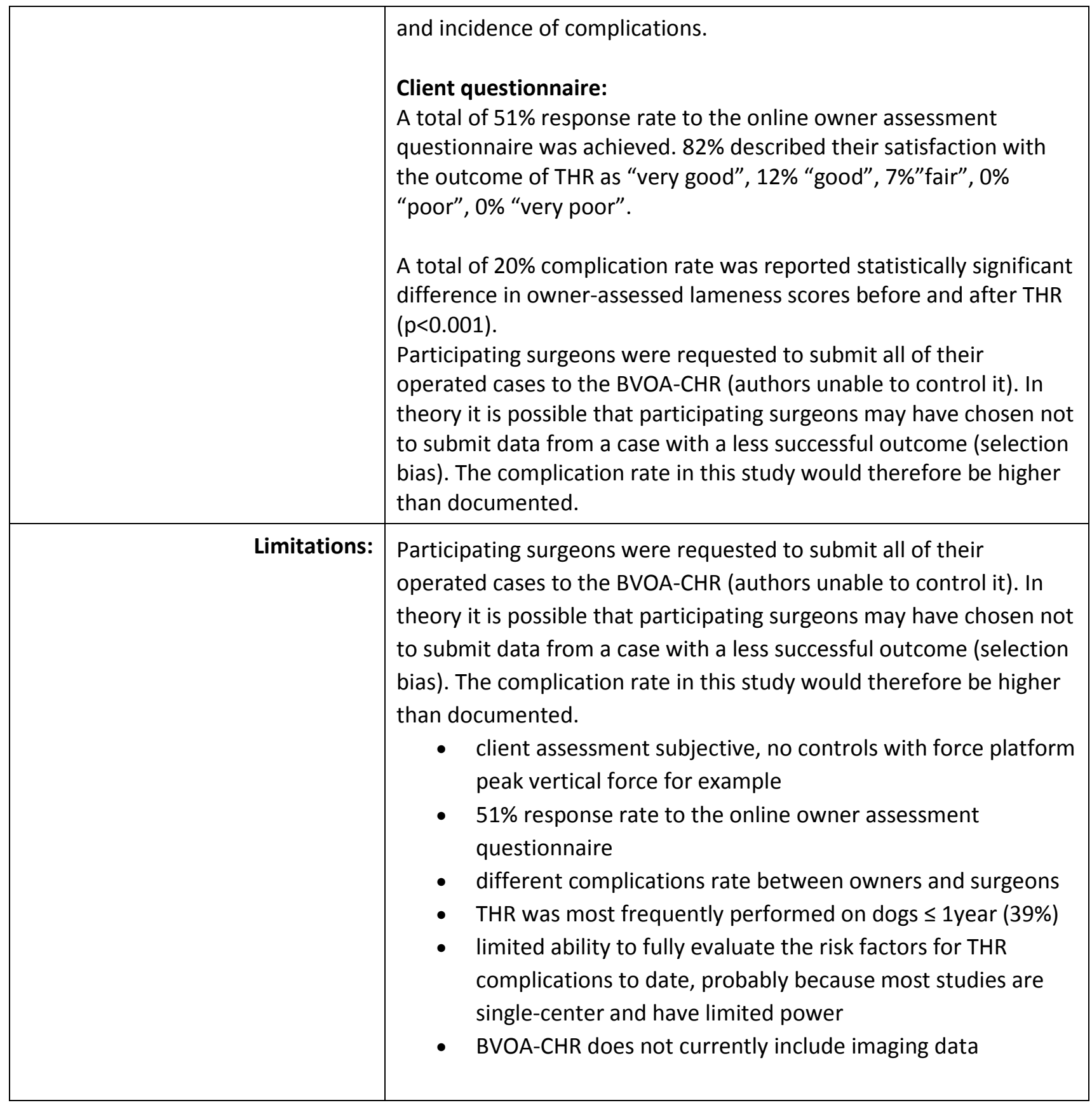

\section{Appraisal, application and reflection}

The aim of this Knowledge Summary was to review, summarise and critically appraise the literature regarding the question: Are old dogs undergoing total hip replacement predisposed for perioperative femoral fractures in comparison to young dogs?

This reflection was investigated in two observational retrospective studies: Liska (2004) and Ganz et al. (2010). Both studies reported that elderly dogs undergoing THR may be at an increased risk of femoral fractures. According to Liska (2004) old dogs with osteopathies, previous hip surgery and iatrogenic fissures created during reaming are predisposing factors for femur fracture after THR. The overall incidence of femur fracture after THR was $2.9 \%$. The author describes an excellent prognosis when the fractures were treated correctly. Due to the design of the study (observational and retrospective) and the limitations (retrospective, different surgeons, surgical method/surgical experience not evaluated as a risk factor, different follow-up) the results have to be interpreted with caution. 
Ganz et al. (2010) evaluated the risk factors for femoral fracture after canine press-fit cementless total hip arthroplasty. The conclusions were that older dogs and dogs with lower CFI may be at increased risk of femoral fracture and the incidence of femoral fracture of cases with complete statistical analysis was $13.5 \%$. Regarding the design of this study (observational and retrospective) and its limitations (retrospective, different surgeons, surgical method/surgical experience not evaluated as a risk factor, different follow-up) the level of evidence provided by this type of study is weak. However, the results of these studies can be used to counsel clients before performing THR in old dogs.

By reviewing the veterinary literature relative to the general complications and outcomes of total hip arthroplasty, a variation in the prevalence of femoral fractures was noticed. None of the studies listed above mentioned that the age of the patient may be a potential risk factor for general complications. Again, due to the design of all of these studies the level of evidence is weak.

In the study of Hummel et al. (2010) the prevalence of femoral fractures occurring intraoperatively was 7.4\%, the prevalence of femoral fractures occurring as short-term complications was $1.2 \%$ and the prevalence of femoral fractures occurring as long-term complications was $0.6 \%$. Increased body weight and prior cemented THR or femoral head and neck ostectomy of the contralateral hip were identified as negative prognostic factors.

Berg et al. (2006) described a 1.3\% prevalence of femoral fracture occurring during the primary THR as short term complications, and fracture of femur diaphysis represented $3.2 \%$ of the long term complications. Eccentric positioning of the femoral stem and the presence of radiolucent lines at the femoral cement-bone interface were positively associated with the occurrence of revision surgery.

The prevalence of femoral fracture post-operatively in the study of Guerrero and Montavon (2009) was 1.5\%. Forster et al. (2012) identified no significant association between weight, age, sex, breed, indication for THR, surgical technique and prosthesis and the incidence of complications of total hip arthroplasty. The incidence of surgeon-reported surgical complications was $9.4 \%$. The femoral fractures represented $18.75 \%$ of the complications.

In conclusion, there is insufficient evidence that elderly dogs undergoing THR are predisposed to femoral fractures in comparison to young dogs. Currently, there are insufficient strongly convincing studies in the veterinary literature to support the results of Liska (2004) and Ganz et al. (2010).

\section{Methodology Section}

\begin{tabular}{|r|l|}
\hline \multicolumn{1}{|l|}{$\begin{array}{r}\text { Search Strategy } \\
\text { covered: }\end{array}$} & $\begin{array}{l}\text { CAB Abstracts (1973-2015) accessed on the OVID platform Vetmed } \\
\text { Resource }(1973-2015)\end{array}$ \\
\hline Search terms: & $\begin{array}{l}\text { dogs OR dogs OR canine AND femoral fractures OR femur OR } \\
\text { femoral OR fracture AND total hip replacement OR total hip } \\
\text { arthroplasty OR cemented total hip replacement OR cementless } \\
\text { total hip replacement OR uncemented total hip replacement OR } \\
\text { cemented total hip arthroplasty }\end{array}$ \\
\hline Dates searches performed: & December 2015 \\
\hline
\end{tabular}




\begin{tabular}{|c|l|}
\hline \multicolumn{2}{|l|}{ Exclusion / Inclusion Criteria } \\
\hline Exclusion: & $\begin{array}{l}\text { Non English language, conference papers, summary updates, case } \\
\text { reports, reviews. }\end{array}$ \\
\hline Inclusion: & $\begin{array}{l}\text { Studies which were looking for risk factors and outcomes in total } \\
\text { hip replacement, studies which described femoral fractures as } \\
\text { complications. Experimental studies and observational studies. }\end{array}$ \\
\hline
\end{tabular}

\begin{tabular}{|l|c|c|c|c|c|c|}
\hline \multicolumn{1}{|l|}{ Search Outcome } & $\begin{array}{c}\text { Number of } \\
\text { results }\end{array}$ & $\begin{array}{c}\text { Number of } \\
\text { duplicates }\end{array}$ & $\begin{array}{c}\text { Excluded - not } \\
\text { English } \\
\text { language }\end{array}$ & $\begin{array}{c}\text { Excluded - } \\
\text { due to study } \\
\text { design }\end{array}$ & $\begin{array}{c}\text { Excluded - did } \\
\text { not answer PICO } \\
\text { question }\end{array}$ & $\begin{array}{c}\text { Total } \\
\text { relevant } \\
\text { papers }\end{array}$ \\
\hline $\begin{array}{l}\text { CAB } \\
\text { Abstracts }\end{array}$ & 194 & 14 & 19 & 34 & 127 & 6 \\
\hline $\begin{array}{l}\text { Vetmed } \\
\text { Resource }\end{array}$ & 7 & 0 & 3 & 1 & 3 & 1 \\
\hline \begin{tabular}{l} 
Total relevant papers when duplicates removed \\
\hline
\end{tabular}
\end{tabular}

\section{CONFLICT OF INTEREST}

The author declares no conflict of interest.

\section{REFERENCES}

1. Bergh, M.S. et al. (2006) Complications and radiographic findings following cemented total hip replacement A retrospective evaluation of $97 \mathrm{dogs}$. Veterinary and Comparative Orthopaedics and Traumatology, 19 (3), pp. 172-9.

2. Forster, K. E. et al. (2012) Complications and Owner Assessment of Canine Total Hip Replacement: A Multicenter Internet Based Survey. Veterinary Surgery, 41 (5), pp. 545-

550.http://dx.doi.org/10.1111/j.1532-950X.2012.01015.x

3. Ganz, S.M. Jackson, J. and VanEnkevort, B. (2010) Risk Factors for Femoral Fracture after Canine PressFit Cementless Total Hip Arthroplasty. Veterinary Surgery, 39, pp. 688-

695.http://dx.doi.org/10.1111/i.1532-950X.2010.00694.x

4. Guerrero, T.G. and Montavon, P.M. (2009) Zurich Cementless Total Hip Replacement: Retrospective Evaluation of 2 nd Generation Implants in 60 Dogs. Veterinary Surgery, 38 (1), pp. 70-

80.http://dx.doi.org/10.1111/i.1532-950X.2008.00466.x

5. Hummel, D.W. Lanz, O.I. and Werre, S.R. (2010) Complications of Cementless Total Hip Replacement A Retrospective Study of 163 Cases. Veterinary and Comparative Orthopaedics and Traumatology, 23 (6), pp. 424-432. http://dx.doi.org/10.3415/VCOT-09-07-0071

6. Liska, D.W. (2004) Femur Fractures Associated with Canine Total Hip Replacement. Veterinary Surgery, 33 (2), pp. 164-172. http://dx.doi.org/10.1111/j.1532-950X.2004.04024.x 


\section{EVIDENCE \\ online}

\section{Intellectual Property Rights}

Authors of Knowledge Summaries submitted to RCVS Knowledge for publication will retain copyright in their work, but will be required to grant to RCVS Knowledge an exclusive license of the rights of copyright in the materials including but not limited to the right to publish, re-publish, transmit, sell, distribute and otherwise use the materials in all languages and all media throughout the world, and to license or permit others to do so.

Authors will be required to complete a license for publication form, and will in return retain certain rights as detailed on the form.

Veterinary Evidence and EBVM Network are RCVS Knowledge initiatives. For more information please contact us at editor@veterinaryevidence.org.

RCVS Knowledge is the independent charity associated with the Royal College of Veterinary Surgeons (RCVS). Our ambition is to become a global intermediary for evidence based veterinary knowledge by providing access to information that is of immediate value to practicing veterinary professionals and directly contributes to evidence based clinical decision-making.

\section{www.veterinaryevidence.org}

RCVS Knowledge is a registered Charity No. 230886. Registered as a Company limited by guarantee in England and Wales No. 598443.

Registered Office: Belgravia House 62-64 Horseferry Road London SW1P 2AF 